\title{
Raúl Ruiz a través del Espejo: de la representación a la alegoría
}

Raúl Ruiz Through the Looking Glass: from Representation to Allegory

\section{Valeria de los Ríos}

Universidad de Santiago de Chile, USACH

vdelosrios@gmail.com

Resumen • El siguiente ensayo está dividido en dos partes tituladas "Del lado de acá" y "Del lado de allá". El objetivo central de este texto es analizar el trabajo del cineasta chileno Raúl Ruiz, tanto en Chile antes del golpe de Estado como en Francia después de éste, y ver algunas continuidades y discontinuidades en su trabajo, en el que se unen las nociones de estética, política, exilio y la posición de un sujeto latinoamericano.

Palabras clave: Raúl Ruiz, cine, alegoría, política, Chile.

Abstract • The following essay is divided into two parts entitled "From This Side" and "From the Other Side". The main objective is to analyze the work of the Chilean filmmaker Raúl Ruiz, both in Chile before the coup, and in France after it, so as to see the continuities and discontinuities in his work, where aesthetics, politics, exile and the position of a Latin American subject coincide.

Keywords: Raúl Ruiz, Cinema, Allegory, Politics, Chile. 


\section{CINEASTA EXPERIMENTAL-INSTITUCIONAL}

Raúl Ruiz nació en Puerto Montt en 1941. Creció en una familia de clase media y su padre fue un capitán de barco. Después de estudiar teología y leyes, abandonó los estudios para dedicarse a escribir, gracias a una beca recibida por la Fundación Rockefeller en 1962. Se dedicó al teatro y escribió más de cien obras antes de pasar al cine. En 1964 asistió a una escuela de cine en Santa Fe (Argentina), y regresó a Chile un año después. Junto a un grupo de intelectuales y cineastas formó parte del denominado "Nuevo cine chileno", siguiendo el ejemplo del brasileño Cinema Novo ${ }^{1}$. Ruiz recuerda que no había muchos cineastas en Chile en aquél tiempo y que todos -o su mayoría- eran amigos entre sí. Tres de los filmes rodados en Chile durante 1968 fueron hechos con la misma cámara². Estas películas no eran caras, y el dinero para financiarlas venía de los mismos cineastas o de algunos amigos. Tres tristes tigres (1968), por ejemplo, costó 10.000 dólares (de esa época) y el padre de Ruiz la financió. Después, con la inversión de la RAI (Radio y Televisión italianas) para un filme (Nadie dijo nada, 1971), financiaron tres películas. En una entrevista publicada en Cine y Cambio Social en Latinoamérica Ruiz relata:

Debido a la nueva ley de impuestos ${ }^{3}$, fue la primera vez que los cineastas chilenos tenían una oportunidad. En Chile, Argentina y otras partes de Latinoamérica en esta época, había una mezcla de avant-gardismo y el deseo de fundar las bases entre los cineastas que habían estado marginados por mucho tiempo. En Chile habían tanto sentimientos de redescubrimiento como una actitud vanguardista: los cineastas estaban emocionados frente al prospecto de hacer una real industria cinematográfica, pero a falta de la técnica usual, tuvieron que adoptar un acercamiento $\operatorname{artesanal}^{4}$ (1986: 186-187).

Ruiz se unió al Partido Socialista, que luego se alió con el Frente Popular que a su vez apoyó a Salvador Allende. Durante la administración de Allende (1970-1973), Ruiz dirigió cerca de 17 filmes, trabajando de cerca con la agencia cinematográfica nacional, ChileFilms ${ }^{5}$. Luego del derrocamiento de Allende, Ruiz viajó a Europa, estableciéndose en Francia.

Se lo define como:"Un cine que ofrece una reflexión amarga de la realidad social mientras desafía las formas dominantes de hacer películas" (Peña, 232).

El Chacal de Nabueltoro (Miguel Littin), Valparaíso mi amor (Aldo Francia) y Tres tristes tigres (Raúl Ruiz). Ley dictada durante el gobierno del demócrata cristiano Eduardo Frei (1964-1970) que facilitó la importación de película en blanco.

En una entrevista aparecida en 1978 en la revista Cahiers du Cinema (número 287) y reproducida en un numero especial de la Filmoteca Nacional de España, Ruiz dijo: "Nos sentiamos mas o menos influidos po el hecho de que en Europa, en el momento en que se produjo la "Nouvelle Vague”, había gente que hacía peliculas que concernían a la vida cotidiana y que estaban haciéndolas con escasez de medios. Nosotros pensábamos también que había que hacer peliculas sobre cosas que se veían a diario pero no teníamos los medios. Y además estaba el ejemplo brasileño que rodaba films totalmente de espaldas al sistema americano de produccion. Esto es lo que se queria hacer. Pero no teniamos ideas claras sobre como construir la máquina de producción porque esta máquina no existía. No se sabía muy bien qué máquina crear y cómo crearla. Eramos simplemente cinéfilos y "cineclubistas". Queriamos hacer películas" (19).

ChileFilms era una institución mixta, que funcionaba desde 1938 con inversión del Estado (CORFO) y capital privado. Después adoptó el modelo industrial, así que fue necesario asegurar la distribución. Ésta estab como Ruiz Littin y Francia durante finales de los sesenta y setenta fue hecho con la cooperación arriendo de equipo y ayuda técnica, de ChileFilms. La Unidad Popular trató de transformar ChileFilms en un instituto de cine, pero como Ruiz cuenta, la oposición era suspicaz, especialmente en cuanto a lo que pudiera suceder en términos de medios de comunicación.
Ahí comenzó a producir filmes a una velocidad alarmante (a menudo seis producciones al año) a un costo prácticamente nulo. Esta maravilla fue posible únicamente gracias a la televisión. De acuerdo con Ruiz, la televisión francesa, auspiciada por el Estado, proveía un enorme espacio de trabajo para un cineasta. Allí hizo las películas que la televisión quería, pero en su propia y particular forma. Por ejemplo, tal como lo describe David Ehrenstein, en 1979 se le pidió hacer una película acerca de las elecciones francesas venideras. Ruiz decidió hacer un filme sobre el impacto de los comicios en su propio barrio, alegando la ignorancia de un exiliado sobre su país adoptivo. El resultado fue Des Grands événements et des gens ordinariez, una pieza de entrevista en la calle, que termina con la parodia al mismo género, pues dentro de la entrevista, Ruiz comienza a desconfiar de su propia habilidad para hacer preguntas y del proceso mismo de pregunta-respuesta. Petite manuel de l'histoire de France (1979) fue encargado como un sencillo documental educacional sobre la historia de Francia. Debido a que el proyecto había sido diseñado para niños de escuela, Ruiz decidió usar niños como narradores de esta historia, resultando con ello un delirante despliegue de diapositivas, películas, juegos y recreaciones de escenas históricas. Muchos de sus proyectos para televisión comenzaron a aparecer también en cine y en el circuito de festivales, hecho que lo llevó a confesar una de las cuantas paradojas de su producción: “¡Me volví un cineasta experimental 'institucional'!” (Ehrenstein, 1986: 5).

El siguiente ensayo está dividido en dos grandes partes tituladas "Del lado de acá" y "Del lado de allá". Los títulos fueron tomados de la novela Rayuela, de Julio Cortázar (1963), que relata la vida de un grupo de exiliados argentinos en París. La idea será analizar el trabajo del cineasta chileno, tanto en Chile antes del golpe de Estado como en Francia después de éste, y ver algunas continuidades y discontinuidades en su trabajo.

Dado que la filmografía de Ruiz es enorme y que muchos de sus filmes son difíciles de encontrar, me centraré en las películas Qué hacer (1970), Palomita blanca (1973) y La hipótesis del cuadro robado (L'Hypothèse du tableau volé, 1977).

\section{DEL LADO DE ACÁ}

Interrogado sobre sus primeros trabajos en el cine, Ruiz dijo: "Yo solo estaba tratando de mostrar algo sobre mi ciudad, la forma en que la gente vivía, cosas así. Era algo que realmente nadie estaba interesado en ver." (Ehrenstein, 1986: 5). Luego, a comienzos de los setenta, se interesó por lo que sucedía en el país -el movimiento popular motivado por la elección de Allende- y quiso participar. Jamás le pidieron hacer algo específico: "Yo era completamente libre de hacer lo que quería" (Burton, 1986: 187).

En 1970 Salvador Allende fue elegido Presidente de Chile, como candidato de la Unidad Popular (una coalición de seis partidos de izquierda), y con el apoyo fundamental del MIR (Movimiento de Izquierda Revolucionaria), el cual estaba fuera de la coalición. A pesar de que Allende carecía de la mayoría absoluta, el Parlamento estuvo obligado por ley, a confirmarlo como el próximo presidente del país. El gobierno de la Unidad Popular se definió a sí mismo como Marxista y comprometido con la transformación revolucionaria del país "por medios pacíficos y constitucionales." La idea que dominó la Unidad Popular era que el país debía primero ganar una batalla económica por la producción entre las restricciones del mismo mercado, establecidas por el imperialismo económico.

En una entrevista realizada en 1980, Ruiz afirmó: 
Recuerdo sentirme muy cercano a Moscú y Stalin por la propaganda anti-Comunista y conocí Recuerdo sentirn muchos que se unieron al partido Comunista como reacción a del Comunismo" que el gobierno incentivaba en libros y películas, y en radionovelas que la mayoría de los niños seguían todos los días. En un determinado momento, parecía haber una conexión vital entre el Marxismo y la situación social y toda una generación se sintió llamada a tomar la lucha. Este movimiento no pudo ser absorbido por el partido Comunista, así que muchos se unieron al partido Socialista y de una fracción de éste se formó el MIR. Solo unos pocos miembros conservadores de esta generación se mantuvieron apolíticos, y también yo naturalmente me volví políticamente activo (Burton, 1986: 184-185).

El mismo año de la elección de Allende, Ruiz trabajó en una co-producción chilenoamericana titulada Oué hacer. La intención original era hacer un film que ayudaría al movimiento popular que estaba desarrollándose en ese momento en Chile. Pero no había una idea clara acerca de qué se trataba el movimiento, así que finalmente, el proyecto resultó un plan fallido. Ruiz relata:

Hice Qué hacer con Saúl Landau. Estaba pensando en un diálogo filmado entre él y yo... Queríamos retratar el aspecto menos heroico de la revolución mundial, algunos temas delavida diaria que también pertenecían al proceso que algún día sería recordado como un todo de una diaria que rificin peto una ( contra la historia. Lo que conenzó cono una aventura libre ternió aparentemente, a travé de un severo sen a consecuencia de debates públicos y cartas sobre el asunto de la cultura y contra cultura, no encontramos cuestionándolo todo. Nuestro grupo se volvió un parlamento. Reconsideramos todo. Cualquiera que apareciera y nos viera grabando, dirigía un par de escenas también. E film presenta tal variedad de puntos de vista que no sé realmente quién la dirigió. Debe haber sido alguien que no conozco (Chanan, 1973: 38).

Qué hacer cubre el breve periodo de tiempo después de la elección de Allende como presidente de Chile y su nombramiento efectivo. El film fue hecho cuando todo este proceso se estaba desarrollando. Retrata dos historias principales y paralelas: primero, la de un chileno auto-exiliado que vive en Cuba y vuelve para ver el proceso revolucionario chileno. Segundo, el de una mujer norteamericana que trabaja en Cuerpos de Paz, y que está involucrada sentimentalmente con un misterioso norteamericano, que podría ser un agente de la CIA.

El filme representa la serie de contradicciones y diversos puntos de vista sobre el "Proceso chileno hacia el socialismo." Cada personaje en la película representa una posición particular dentro de este proceso. No hay una única respuesta correcta o conclusión al final de filme. La pregunta permanece abierta, como una exclamación, como la misma tipografía del filme lo indica. Los signos de exclamación aluden a una urgencia que es relatada en la proximidad de las elecciones. Hacia el final de la película, hay una conexión con el evento histórico real: las últimas imágenes muestran la ceremonia de nombramiento de Salvador Allende como Presidente de Chile, y la celebración pública de su elección.

Aunque Ruiz es muy crítico ${ }^{6}$ con este filme, es interesante la manera colectiva en que fue hecho, y la relación que uno puede establecer entre la película y su contexto, es decir, entre

"Qué hacer Es una película que habría que olvidar porque nunca nos pudimos poner de acuerdo sobre el modo de cómo habría que realizarla. Es un fracaso para mí, pero no porque se tratara de una coproducció americana. Trabajamos con gente de izquierda, llenos de buenas intenciones, pero para los que era difíci la ficción y la realidad, y -dentro de la película misma- entre las imágenes escenificadas y las documentales. El uso del estilo documental responde a elección estética, y a una vinculación con el contexto. ${ }^{7}$ Cuando Deleuze describe la imagen-tiempo habla específicamente de situaciones ópticas y sonoras no asociadas necesariamente con la imagen-movimiento (nexo sensorial motriz). Esto es exactamente lo que sucede con las escenas de multitudes en Qué hacer, donde los distintos grupos demuestran sus preferencias políticas, evidenciando la división existente entre los partidarios de los tres candidatos presidenciales: el de derecha Jorge Alessandri, el Demócrata Cristiano Radomiro Tomic y el Socialista Salvador Allende. Como en algunas películas de Einsestein, las masas son aquí un personaje más del film. Las imágenes y sonidos de la multitud -canciones, slogans políticos- no están relacionados (en términos narrativos) con las acciones dentro de ella, pero otorgan sin duda un nexo con su referente.

La conexión con la realidad está también presente en el uso de entrevistas. En ellas se hace visible la presencia de la cámara: sabemos como espectadores, que la "persona real" (gente anónima de la multitud, el candidato Salvador Allende y un militante del MIR encarcelado) está frente a la cámara, con un micrófono. El caso del militante es paradigmático, ya que su testimonio es el único realmente "consciente" del proceso cinematográfico. Él es un intelectual de la clase trabajadora,-como Gramsci diría, "un intelectual orgánico" - que hace constantes referencias a la película, a la forma en que está siendo filmada, y al mismo tiempo, critica su narrativa. Por lo tanto, su consciencia existe no sólo en un nivel cinemático, sino también en el nivel de la experiencia. Siguiendo esta idea, hay una intertextualidad muy interesante en Qué hacer. La película tomó su nombre del libro Qué hacer: problemas candentes de nuestro movimiento. El libro de Lenin fue publicado en 1902, cuando todavía no existía el Partido Comunista en Rusia, sino sólo el movimiento Social Demócrata. Lenin estaba preocupado de la producción de teoría revolucionaria para apoyar el movimiento revolucionario, por lo que incentivó el desarrollo de líderes socialistas de la clase obrera.

Los dos personajes principales -el auto-exiliado y la mujer nortamericana-se dedican a observar la situación chilena, y no actúan sobre ella. Es importante notar que ambos vienen de fuera del país: él de Cuba y ella viene de los EE.UU. Por un lado, la mujer tiene una visión de postal del paisaje de Chile y un acercamiento documental a la condición social de las clases bajas en Chile. En las escenas "vistas" desde su perspectiva (más cercanas a un estilo indirecto libre que a la cámara subjetiva), hay una indeterminación entre lo imaginario y lo real, porque el estilo del montaje interrumpido muestra una desconexión entre el tiempo y el espacio. No estamos seguros, por ejemplo, si las escenas del "affaire musical romántico" con el potencial agente de la CIA, sucedieron realmente o fueron imaginadas. Por otra parte, el chileno expatriado duda que los enemigos de Allende lo dejarán gober-

entender la realidad latinoamericana, y por eso el film es tan ingenuo y simplista, lleno de clichés norteamericanos sobre nuestro país" (Ruiz, 12).

"En esta época, había muchos problemas políticos, huelgas, etc y estábamos bastante atontados porque queríamos filmar en calles vacías y siempre había gente que luchaba con la policía en las calles, etc. Así fue como empecé a disfrutar del espectáculo. El desajuste entre lo que rodaba y lo que pasaba me producía los deseos de mezclar las dos cosas" (Ruiz, 21).

8 Para Gramsci un intelectual orgánico es opuesto al intelectual tradicional. Un intelectual orgánico destaca de grupo mismo y tiene una participación activa en la vida práctica como constructor, organizador y "persuasor permanente". 
nar, y con ello se sitúa en una posición intermedia entre las explicaciones racionales de su amigo comunista que cree en la "vía chilena" al socialismo y el romanticismo radical del hijo de éste, que ve en el triunfo de Allende una continuación de la hegemonía burguesa. Dado que este personaje actúa como un espectador, invierte los objetos y locaciones con su mirada irónica. El personaje narra la historia de una forma extraña, porque no está siempre presente (él no es omnisciente, por lo tanto no lo ve todo) y los eventos que relata no están claramente presentados en un orden cronológico. La estética recién descrita se conecta directamente con el cine de poesía de Pasolini. Según Deleuze, en los filmes de Pasolini el personaje actúa en la pantalla y el espectador asume que éste ve el mundo de cierta forma. Pero simultáneamente, la cámara ve al personaje y a su mundo desde otro punto de vista, que piensa, refleja, y transforma el punto de vista del personaje.

Cerca del final de la película, la mujer norteamericana decide renunciar a su trabajo en los Cuerpos de Paz y convertirse en revolucionaria. En este punto, conoce al chileno auto-exiliado que la lleva a un pueblo donde viven los "verdaderos revolucionarios". Ahí él, distanciado del personaje, narra a través de una voz acusmática cuán diferentes son las respuestas a la pregunta "¿Qué hacer?": desde un punto de vista individual (en este caso, el de la mujer norteamericana) y desde una perspectiva colectiva (la de los revolucionarios).

En cierta forma, estos dos personajes son opuestos al militante encarcelado (el intelectual de clase obrera entrevistado), porque él es una "persona real" que habla sobre el film, mientras que los personajes son ficticios y tratan de interpretar la realidad. Los personajes que "ven", son aquellos que quieren encontrar un punto de vista desde el cual pensar. Por lo tanto, su posición es previa al discurso (están solo percibiendo).

La búsqueda del punto de vista explica la experimentación visual dentro del film. En 1970, hablando sobre su trabajo con tomas alienadas en Tres tristes tigres, Ruiz dijo:

Fui influenciado por la nouvelle vague más que por el Neo-realismo. La idea era poner la camara no donde viera mejor, sino donde debería estar, en la posición normal. Esto significa que siempre hay alguna obstrucción y las cosas no son vistas desde una postura ideal. También había una tendencia antidramática, trabajando contra la narrativa, favoreciendo los momentos privilegiados; el estilo era anticomposicional, usando el fuera de campo, con cámara en mano (a excepción de la última secuencia de pelea). Pero la intención no era reproducir el estilo nouvelle vague. Tambén hab́a un intento para enfrentar la vergienza de prododre ex mexicano con un tipo de inversión, como si la cám

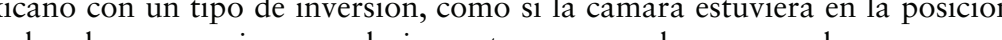
opuesta, mostrando a los personajes secundarios, extras esperando para que la gran escena

La posición no privilegiada de la cámara constituye un intento por atrapar el realismo de la vida diaria, y al mismo tiempo, es un esfuerzo por romper las convenciones del melodrama mexicano. La idea de mostrar la imagen siempre con algunos obstáculos visuales es también una herencia del Cinéma vérité, que trataba de poner en cuestión los modelos cinemáticos de verdad. En Qué hacer podemos ver este tipo de configuración, especialmente en la escena de la comida en la casa del diputado comunista. El espectador es siempre puesto en una posición diferente, mirando detrás de los hombros del personaje.

Ruiz tiene su propia idea de realismo, contrario al realismo mimético y más cercano a "cierto realismo" 9 de Pasolini. Para el cineasta, el lenguaje es un discurso sobre el mundo y el cine un discurso del mundo. Como afirma Viano -y esto también es válido para Ruiz ${ }^{10}$ Pasolini estableció que el cine era el lenguaje escrito de la realidad y que la realidad era el cine en la naturaleza.
(Viano, 1993: 22).
"Pasolini no sólo quería 'representar' la realidad. Más bien, sus filmes apuntaban a poner a los espectadores en la posición de hacerse a sí mismos preguntas sobre la realidad" (x-xi)

La pregunta sobre la realidad es puesta en Qué hacer en la forma de la auto-reflexividad. Hay algunas imágenes e incluso una canción que habla sobre el hecho de hacer la película. Esta estructura mise en abîme no es sólo un "dispositivo postmoderno," sino una revelación de los "modos de producción," dejando claro que lo que vemos es un filme, y no la realidad, al modo del "Esto no es una pipa" de René Magritte. Después de esta película Ruiz tomó distancia del trabajo directo con la realidad. En una entrevista de 1978 declaró:

Quizá soy más sensible que los demás cineastas chilenos en el exilio a las determinaciones creadas por las condiciones de rodaje, ya que mis filmes tienen la característica de ser reflexiones sobre un problema político y sobre la manera en que se está rodando tal problema político. Por eso es por lo que a veces se comienza desarrollando algunas imágenes con un talante más bien épico y se acaba por poner en cuestión ese talante (Ruiz, 16).

La Expropiación (1971), por ejemplo, fue hecha en el mismo tiempo en el que el MIR se había vuelto crítico hacia la Unidad Popular. La idea era trabajar con una situación que aún no era explicada por la teoría general. Ruiz estaba tratando de mostrar qué sucede cuando la teoría es contradicha por la realidad, y las paradojas sociales emergen de generalizaciones. Se supone que cuando la tierra es entregada a los campesinos, ellos estarán felices, pero esto no necesariamente es así. En el filme, un agrónomo tiene que expropiar un fundo. Llega al lugar y es recibido con honores por el dueño de la tierra. Mientras conversa con él descubre que estudiaron en la misma escuela, y que pertenecen a la misma clase social. Repasan sus recuerdos escolares, las cosas que tienen en común, etc. En la noche, se lleva a cabo un baile en honor del agrónomo, al que asisten los ancestros del dueño, en un desfile de fantasmas, que pretenden proteger su propiedad: granjeros, propietarios, sacerdotes y soldados. Al día siguiente, los campesinos aparecen rehusando la expropiación. Amenazan al agrónomo y finalmente lo matan.

En Palomita Blanca ${ }^{11}$ Ruiz trabajó directamente con estereotipos sociales. El estereotipo es un modelo que intenta explicar a un sujeto real, quien por supuesto siempre es mucho más complejo que su simplificación. El filme está basado en un best seller local, una historia de amor escrita por Enrique Lafourcade. La narración es la aventura romántica de una joven mujer de los suburbios de Santiago y un joven de la clase alta chilena. Ambos personajes están interpretados por no-actores, que fueron escogidos en una competencia abierta, registrada en el documental del propio Ruiz, Palomita brava (1973).

La historia es contada como un racconto desde el punto de vista de la joven, una suerte de diario, narrado por la voz en off de la protagonista. No hay una narración cronológica y a menudo algunas acciones son relatadas más de una vez. En cierta forma, la memoria, con todas sus imperfecciones, es el hilo conductor de la historia. El narrador-protagonista,

10 En una entrevista grabada en Chile antes del golpe de Estado, Ruiz declara: "Si, además, como en mi caso, eres militante de un partido marxista, tienes que reflexionar sobre ciertos eventos. Te das cuenta [sic] de que los instrumentos de información, una vez concentrados en las manos de la derecha, pronto pertenecerán a la izquierda. Esto aun no es lo ideal que, como marxistas [sic], estamos buscando. Pero significa que si nada más, habrá una forma de crear un cine que posibilite una mayor participación, un cine dotado de una mayor posibilidad de análisis, más abierto a la vida diaria, un cine que verdaderamente trate de transformar nuestra realidad. Lo que obviamente no significa hacer películas que inciten golpes, sino películas que nos ayuden conocer la realidad que se quiere cambiar" (Chanan, 1976: 40). durante los 17 años de la dictadura. Fue exhibida en los cines chilenos por primera vez en 1992. 
en otras películas de Ruiz, no es omnisciente y nosotros, como espectadores, vemos más de lo que ella ve. En términos visuales, Ruiz juega otra vez con los puntos de vista no privilegiados, como si la posición del espectador estuviera dentro del entorno, como un voyeur (la historia es contada como un diario, el cual es, por definición, un lugar para la escritura privada). La protagonista es una especie de "Madame Bovary," que en lugar de leer novelas, ve telenovelas. Ambas producciones -novelas y telenovelas- son un entretenimiento masivo por excelencia. Dentro de la película, podemos ver algunos capítulos de la telenovela que sigue la protagonista. Estos hilarantes fragmentos muestran la rigidez y absurdo de este tipo de género, y al mismo tiempo, develan el quiebre con las actuales condiciones de vida del personaje principal. ${ }^{12}$ La historia que cuenta la protagonista es muy melosa, como la historia de una telenovela, pero el contraste con el contexto en el que ella y su familia viven hace la diferencia. Ella intenta vivir como si fuera la protagonista de una telenovela, pero sus condiciones de vida exceden e incluso contradicen su esfuerzo. En un nivel cinematográfico, podemos experimentar la dislocación comparando lo que escuchamos y lo que realmente vemos: hay un gran contraste entre las narraciones en off y las imágenes filmadas. A pesar de que la protagonista es ciega frente a sus propias condiciones de existencia, se la presenta como una especie de heroína. Este carácter heroico es reafirmado por la música, la cual acompaña a la protagonista donde quiera que vaya.

El contexto de la historia es nuevamente la época de las elecciones, pero ella no está realmente interesada en la elección, a pesar de que habla sobre esto una vez, porque era el tema público más importante del momento. Dice que le gusta más Alessandri, el candidato de derecha, mientras el protagonista masculino es miembro de un movimiento no político liderado por el gurú Silo (un movimiento de influencia hippie). Más que una película directa o políticamente discursiva, este filme muestra las inequidades y la división de clases en Chile durante los setenta, así como también los modelos establecidos por los medios de comunicación masivos.

En una entrevista hecha después del golpe de Estado, Ruiz dijo:

El proceso político nos empuja hacia la producción de un tiempo de cine que pueda ser útil inmediatamente, un cine útil. Nos sentimos impulsados hacia eso por las circunstancias. Indudablemente, cuando te entregas a este compromiso, descubres, poco a poco, elemento y rastros de la cultura de la resistencia[...] La gente y los personajes son bloques de hielo flotantes que muestran muy poco de ellos mismos y mantienen lo más importante sumergido ${ }^{13}$ (Chanan, 1976: 31).

Por "cultura de la resistencia” Ruiz entiende la síntesis de las técnicas de rechazo a un orden establecido. Él declara que las reglas de rechazo corresponden a lo que definimos como civilización (aprender a leer y escribir y a comportarse de una manera "civilizada") y también técnicas de cancelación, como el alcoholismo y otras transgresiones más sutiles a las normas establecidas:

12 Aquí estamos confrontados a la definición de Althusser de ideología, y también la idea de John Berger de insatisfacción marginal, no aplicada ahora a la publicidad, sino a los programas de televisión

13 Ruiz declara: "Uso el cine como un espejo sabiendo que me da una imagen invertida. Uso el cine como un espejo deformante. Me doy cuenta de que veo la realidad con mis ojos y el cine, gracias a las distorsipur.
Creí que era más importante crear el país que el cine. Y este programa [sic], que parece tan obvio, el cual todos los cineastas chilenos [sic] defienden en sus manifiestos, nos lleva a ciertas

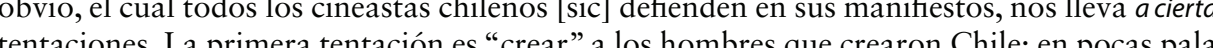
tentaciones. La primera tentación es "crear" a los hombres que crearon Chile; en pocas palapras, consagrarnos a la exalación de cruestros supuestos héroes nacionales, héroes populares, para fomentar la popularidad de esos héroes, haciendo películas sobre O'Higgins, Manuel Rodríguez y otros monstruos sagrados. La creación de este tipo me parece suficientemente fácil, pero bastante peligrosa (Chanan, 1976: 30).

Entonces, para Ruiz era fundamental dedicarse a un cine que promoviera la auto-identificación, o mejor dicho, la auto-afirmación en todos los niveles, incluso en los negativos. Desde aquí podemos entender la importancia del lenguaje hablado para Ruiz. La forma en que los personajes en sus filmes -actores y no actores- usan el lenguaje refleja este tipo de auto-afirmación. Hay a menudo escenas en sus películas que son realmente intrascendentes para la trama central -las escenas del bar en Qué hacer, y la escena de la clase en Palomita blanca, por ejemplo-, pero que dan un tipo de información que tiene que ver con esta "cultura de la resistencia", a partir del registro de la oralidad chilena.

\section{DEL LADO DE ALLA}

Diálogo de Exiliados (1974) fue el primer filme hecho por Ruiz fuera de Chile y para él usó un texto de Brecht como punto de partida. El filme quería retratar las dificultades de una organización política en el exilio. Como Ruiz describe, durante la filmación aparecieron los problemas y cuando fue estrenado, los chilenos en el exilio lo vieron como una crítica inoportuna. Ruiz relata que la película fue hecha con muchas dificultades. Los materiales para su producción eran muy reducidos: tenían la solidaridad de algunos técnicos franceses y algunas personas que les daban crédito para comprar la cinta. Ruiz y todos los actores en la película eran exiliados y -como cuenta el propio director-todos ellos tendían a reírse, a tomar una actitud irónica hacia lo que estaban haciendo y hacia los grandes problemas que querían retratar. ${ }^{14}$ Paul de Man define ironía como un signo que apunta a algo que difiere de su significado literal y que tiene por función la tematización de esta diferencia. De Man la describe como una folie lucide, que permite al lenguaje prevalecer homogéneo en etapas de auto-alienación. Ruiz confiesa: "Nosotros estábamos ante todo impresionados por el hecho de haber contribuido a una de las mayores derrotas del proletariado mundial. Nos sentíamos responsables ${ }^{15}$ y eso explica nuestra posición irónica” (Ruiz,17).

1 Ruiz dijo: "Ciertamente, es un filme muy amargo -podría ser visto como negativo- pero la amargura tiene que ver con la moral de los exiliados" (Burton, 1986:188).

En 1978, Ruiz dijo lo siguiente: "Cualquiera que sepa leer y escribir, que tenga un mínimo de formación y que viva en un país del tercer mundo es responsable de lo que pasa. Esto no es una responsabilidad abstracta, sino muy concreta. Yo, por ejemplo, que era encargado de hacer films y que realizaba films de propaganda como miembro del Partido Socialista, intentaba trabajar como adjunto del Departamento de Comunicación del Partido, cosa que significaba trabajar con un sindicato de proyeccionistas y obreros del cine, a la vez que realizar películas de propaganda y tambien películas de reflexion, etc. [...] Así, pues, evidentemente éramos responsables. Cuando tu declaras to 
Este filme es el último hecho de modo más realista y marca el comienzo del periodo "ilusionista" de Ruiz. Como Zuzanna M. Pick asegura, en Francia el cineasta se vio forzado a adoptar cierto grado de profesionalismo, como por ejemplo, la idea de esbozar un guión escrito. Sin embargo, Ruiz no renuncia a los métodos de filmación informal de sus primeros trabajos, ya que como Waldo Rojas ha descrito, la situación fílmica le provee "un punto de partida para romper los estándares disponibles y los códigos, para de-construir y re-construirlos" (177).

Ciertamente el trabajo de Ruiz en Francia refleja un virtuosismo cinemático. En un modo coherente, Ruiz comenzó a trabajar de acuerdo a su nueva condición de cineasta chileno exiliado en Francia. Su trabajo aquí puede ser caracterizado como cine barroco (Buci-Glicksmann): en estas películas vemos una multiplicación de puntos de vista, el uso de composiciones con profundidad de campo, algunos objetos ampliados, la presencia de una perspectiva extraña, y del close up (algunas veces la parte es más grande que el todo), etc. Él trabajó con la colaboración de experimentados directores de fotografía como: Sacha Vierny y Henri Alekan. En ese momento: "El cineasta ha adoptado un modo de filmar altamente estético caracterizado por una asombrosa variedad de tomas y complejos escenarios que intensifican prolijos soundtracks y performances teatrales" (Pick, 1993: 178).

L'Hypotèse du tableau volé comenzó como una propuesta hecha por Ruiz para hacer un film sobre las teorías estéticas de Pierre Klossowski para la serie de televisión francesa Camera Je. Este filme en blanco y negro tiene la forma de un documental de historia de arte. La voz en off otorga varias hipótesis sobre el trabajo de Tonnerre, un oscuro pintor. El coleccionista, que es la persona entrevistada en este documental, relata la historia de un escándalo que se levantó sobre el significado del trabajo del pintor. Explica que el significado del grupo de cuadros puede ser solo comprendido a través de la existencia de una séptima pintura, existencia que no puede probar. Toda la película es un paseo por las pinturas representadas como tableaux vivants. El coleccionista trata de revelar los misterios en las pinturas -los extraños patrones de luminosidad, las figuras que se agrupan, las referencias teológicas, etc.- y dar una interpretación consistente de ellas.

La cámara se mueve como si estuviera sobre ruedas, con un estilo muy similar al de Último año en Marienbad de Resnais (el director de fotografía es, en ambos casos, Vierny). Esto produce un cierto sentido de irrealidad, porque nosotros -como espectadores- seguimos la cámara que se mueve hacia el tableaux muy rápidamente: subimos las escaleras, entramos en diferentes cuartos, vamos al jardín y después al sótano. En este trayecto, perdemos el real sentido del espacio.

Frecuentemente el narrador en off -al que identificamos con la cámara- no está de acuerdo con las teorías del coleccionista e interrumpe su discurso. Aquí nos encontramos nuevamente frente a un quiebre entre lo que vemos y lo que escuchamos. ${ }^{16}$ Por ejemplo, hay muchos casos en los que el coleccionista nos invita -al narrador, la cámara, los espectadores- a ver algún detalle específico, o a ir a una posición cercana a la ventana. Pero la cámara, en vez de seguir esta sugerencia, hace algo completamente diferente; la palabra, la voz no controla la imagen, o en otras palabras, la imagen excede a la palabra. ${ }^{17}$

El viaje de una tableaux al otro, siguiendo la interpretación del coleccionista, evoca el proceso básico del movimiento cinematográfico, una idea que Barthes encontró en el teatro

16 Steven Shaviro afirma: "La separación entre discurso e imagen refleja la incapacidad del lenguaje (metáfor imagen subsiste como un rastro o un residuo, ajeno al proceso de significación” (30). de Brecht y en las películas de Einsenstein. Pero también retrata -como indica Peña- la elusividad del significado cinemático. La figura del coleccionista es similar a la del detective: intenta develar el enigma donde sólo vemos pintura convencional. La idea es hacer visible lo que no se ha visto, lo que es, en un sentido general, la meta del proceso de interpretación en sí. Por ejemplo, usando las posibilidades presentadas por la técnica del tableaux vivant, el coleccionista cambia los patrones de iluminación, permitiéndonos ver lo que quedaba lúgubre, algo que es imposible en términos de una pintura real. Pero el significado permanece siendo un misterio es desplazado de tableaux a tableaux y finalmente, el coleccionista pone en cuestión su propia teoría: la tesis de la existencia de una "sociedad secreta" que lleva a cabo "la ceremonia," un tipo de ritual pagano prohibido, cuya existencia explica el escándalo producido por los lienzos.

Como en muchas de las películas de Ruiz, los personajes son fantasmas. En el caso específico de L'Hypotèse, los intérpretes de los tableaux son las sombras, esos muertos vivientes que son la única compañía del coleccionista. Podemos argüir la presencia de un sistema cerrado: el coleccionista vive rodeado de figuras fantasmales a las que no puede conferir un significado. Cuando nosotros -como espectadores identificados con los movimientos de la cámara- dejamos la casa al final del filme, vemos que el coleccionista -nuestro Virgilio o nuestra Ariadna- se quedará en medio de este mundo de sombras. Pero hay un exterior, que no es ni para el coleccionista, ni para el narrador identificado con la cámara y que aparece cuando la pantalla se va a negro y la única cosa que permanece es el ruido de las calles.

La idea de un "sistema cerrado" sumado a la noción de "código perdido" sugiere una conexión con la alegoría Para Benjamin, alegoría es donde "cualquier persona, cualquier objeto, cualquier relación puede significar absolutamente cualquier cosa" (175). Laleen Jayamanne arguye:

El trabajo alegórico de Baudelaire fue una respuesta al shock de la modernidad, mientras para Ruiz la pérdida de tradición está marcada por la diáspora chilena. Es una posición de pérdida de país, lenguaje e identidad que Ruiz comienza a recuperar la pérdida alegorizando el momento de la ruptura ${ }^{18}$ (1995: 236).

Uno podría discutir que L'Hypotèse du tableau volé es una alegoría de la condición de exiliado, en el sentido que el exiliado ha perdido la posibilidad de otorgar significado a sus nuevas circunstancias. Ha perdido el código para interpretar la realidad, su condición es ahora la del alienado. Tal como arguye de Man, la alegoría designa una distancia con relación a su propio origen, renunciando a la nostalgia y el deseo de coincidir con ésta. La alegoría se refiere a otro signo que le precede. Entonces, el significado constituido por el signo alegórico puede solo consistir en la repetición de un signo previo con el cual no puede coincidir más, ya que "es de la esencia de este signo ser pura anterioridad." La alegoría establece su lenguaje en el vacío de su diferencia temporal.

La alegoría ha estado siempre (en la crítica reciente) relacionada al barroco, no solo como un periodo histórico, sino también como un estilo estético. El barroco popular es una práctica de economía, porque su idea es poner el máximo en el mínimo. Para Ruiz, el

17 Cuando se le preguntó por sus sentimientos después de regresar por primera vez a Chile tras diez años de exilio, Ruiz dijo: "La primera vez fue un impacto. Me sentí como un muerto viviente, no era un sentimiento 
barroco no es solo un modo de producción europeo, sino también una viviente tradición latinoamericana. Las alegorías del exilio en las películas de Ruiz son al mismo tiempo relacionadas a la condición Latinoamericana. Para el realizador: "la experiencia Latinoamericana es estar fuera (o dentro) de la cultura europea en general, mientras que la europea está dentro de una cultura específica u otra" (Burton, 1986: 191). En una entrevista publicada en Cahiers du Cinéma, Ruiz describió tres actitudes chilenas características:

Aquella de Lautaro, un indio que fue tomado como amigo por los españoles y quien estudió meticulosamente sus métodos con ningún otro motivo que el de usarlos contra sus amos. La de Jimmy Button [sic], un indio iletrado adoptado por el capitán del 'Beagle' en el primer viaje de Darwin: aunque aprendió inglés en tres semanas, fue a Oxford e incluso llamado al Bar, olvidó todo en su regreso a Sudamérica. Y la de Valderomat [sic], el Óscar Wilde chileno, que era el querido de los salones antes de ahogarse en una alcantarilla. Al preguntarle con cuál de ellos se identificaba, Raúl respondió "Tengo la sensación de que floto de uno a otro..." (Pick, 1993: 184)

Ruiz sentía la necesidad de explicar Latinoamérica a sus amigos europeos y Europa a sus amigos latinoamericanos. Algunas de sus películas son puentes entre el cine que le gustaría hacer en Latinoamérica y el cine que hace en Europa

Usando el mecanismo de la narración y los tics estilísticos para doblar la traducción, he hecho películas que pueden ser vistas por dos culturas. Como lo emocional siempre tiende a fallar, decidí contar -a través de metáforas y de la multiplicación de retóricas cinematográficashistorias de familias dispersas en las cuales la condición latinoamericana $[\ldots]$ es primordia (Pick, 1993: 179).

Se podrían dividir los primeros trabajos de Ruiz de sus trabajos hechos en Francia en la misma forma en que se hace la división entre representación y alegoría. En este sentido, sería fácil recordar la afirmación del realismo de Jameson como la forma del Modernismo (imperialismo y capitalismo monopólico) y la alegoría como la representación de Postmodernismo (capitalismo tardío). Pero tales divisiones podrían ser sostenidas solo a un nivel muy general. Como asegura de Man, la ironía y la alegoría han estado siempre ligadas. Ambas se refieren a la relación discontinua entre el signo y su significado. Las dos son caras de la misma experiencia fundamental de tiempo: la ironía es una estructura sincrónica, mientras la alegoría aparece como una forma sucesiva capaz de engendrar duración como la ilusión de la continuidad que sabe es ilusoria. Pero el lenguaje -en caso de cine- es siempre representacional y no-representacional al mismo tiempo. De Man afirma en referencia a la poesía:

El poder alegórico del lenguaje socava y oscurece el sentido literal específico de una representación abierta para el entendimiento. Pero toda la poesia alegorica contemporánea debe contener un elemento representacional que invita y permite el entendimiento, solo para descubrir que el entendimiento al que llega está necesariamente errado (1983: 185).

En películas como Qué hacer, Palomita blanca, Colloque des chiens y L'Hypotése $d u$ tableau volé es posible ver cómo Ruiz juega con diferentes niveles de representación, algunos de ellos realistas y otros fantásticos. Incluso en sus películas más "realistas" tenemos la presencia de la narración en off que funciona como memoria, como una guía no ordenada o un límite, que produce el asombroso efecto de estar al mismo tiempo dentro y fuera del espacio de la narración. Lo mismo puede ser dicho sobre el encuadre "sucio" de sus primeros filmes. Nunca hay un intento de reproducir la realidad de una forma mimética. Por otra parte, en sus films franceses podemos corroborar que utiliza las convenciones cinematográficas del realismo para producir un efecto irreal: si en L'Hypotèse du tableau vole usa la forma de documental de arte, en Le Toit de la baleine se sirve del documental antropológico. Todas las películas que hemos analizado muestran y hablan sobre la experiencia de estar afuera, de la alienación y la dislocación, lo que para Ruiz es una alegoría de la condición latinoamericana.

\section{REFERENCIAS}

Benjamin, Walter. (1998). The Origin of German Tragic Drama. New York: Verso. Burton, Julianne. (1986). Cinema and Social Change in Latin America. Austin: University of Texas Press.

Chanan, Michael. (1976). Chilean Cinema. London: British Film Institute.

De Man, Paul. (1983). Blindness and Insight. Minneapolis: University of Minnesota Press. Ehrenstein, David. (1986). "Raúl Ruiz at the Holiday Inn”. En: Film Quaterly. Fall: 2-7.

Jayamanne, Laleen. (1995). "Life is a Dream”. En: Kiss me Deadly: Feminism \& Cinema for the Moment. Sydney. Power Publications: 221-251.

Peña, Richard. (1990). "Borges and the New Latin American Cinema". En Borges and his Successors: The Borgesian Impact in Literature and the Arts: 226-243. Columbia: University of Missouri Press.

Pick M., Zuzana. (1993). The New Latin American Cinema. A Continental Project. Austin: University of Texas Press.

Ruiz, Raúl. Raúl Ruiz. Filmoteca Nacional de España.

Shaviro, Steven. (1993). The Cinematic Body. Minneapolis: University of Minnesota Press.

Viano, Maurizio. (1993). A Certain Realism: Making Use of Pasolini's Film theory and Practice. California: University of California Press. 